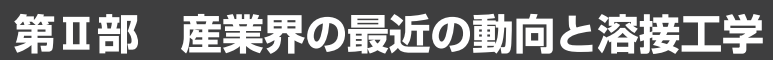

\section{IV 品質保証と管理}

\section{2. 非破壊検查技術}

\section{大 岡 紀 一*}

\section{Nondestructive Inspection Technique}

by OOKA Norikazu*

キーワード：非破壊検査，非破壊試験関連規格，ISO 規格，内部検査，表面検査，放射線透過試験，超音波探 傷試験

\section{1 概要}

各種プラントの機器・配管，建築，橋梁，運輸等の大 型構造物，それらを構成する部材等の製造過程及び保守 保全において，非破壊検查は品質保証及び品質管理の目 的を達成するための一手段である。一般に，溶接構造物 における溶接部に対しては最終的に溶接終了後に外観検 查，磁粉探傷検査，浸透探傷検査等の表面検查や放射線 透過検査，超音波探傷検查等の内部検査が実施されるだ けでなく，溶接前には開先検査など，溶接中には多層盛 溶接の層間や裏はつり部の検查などに表面検査が適用さ れる場合がある。一方，機器等の状態監視，診断に $\mathrm{AE}$ （アコーステックエミッション）試験及びサーモグラフィ 試験が適用されてきている．対象となるきずは品質管理 の面からそれを検出するだけでなく，その試験結果は設 計及び製造工程にフィードバックされ，それらの改良・ 改善に有益となる。すなわち, ISO9001（品質マネージメ ントシステム）に拈けるPDCA サイクルのCheckにおい て重要な役割を果たすことになる．非破壊検查によって 最終製品の健全性を確保することは保全などにおいても 供用期間中の各種プラントの機器や配管, 輸送用機器, 建築，橋梁等の安全性を維持していくことに繋がってい くことである．保全などにおいて非破壊検查の対象とな る損傷は材料劣化，割れ及び腐食減肉などであり，使用 されている材料，使用環境，運転条件，過去の履歴等に よりその発生形態が異なるので，これらに留意して適用 する非破壊検査手法等を選定する必要がある。一方，非 破壊検査を実施した場合にその結果の精度と信頼性につ いては，適用した試験方法及び試験条件が妥当であるか 否かを事前に確認することが望ましいが，模擬試験体の 製作や非破壊試験実施後の切断試験による確認を行打う とすると必ずしも経済的とは言えない。このため，例え

原稿受付 平成 20 年 3 月 26 日

（社）日本溶接協会 The Japan Welding Engineering Society
ば放射線透過試験では透過度計や階調計を用いて透過写 真の像質を管理あるいは評価することによって，間接的 に試験方法及び試験条件の妥当性の確認を行っている. この他に試験装置が所定の性能を満足していること及び 試験技術者の力量（必要な技量・資格を有していること） が規定される．このように規格・基準に従って試験・検 查を実施することによって，ある品質レベル以上の試 験・検査結果が得られるように管理が行われていること になる。

\section{2 全体の関連規格及び試験技術の動向}

非破壊試験を実施する際には信頼性のある客観的な結 果を得るために，一般に非破壊試験技術に係わる規格・ 基準が引用される。その最も代表的なものは日本工業規 格（JIS）であるが，原子力や火力発電プラント，石油石 化・化学プラント等の公共性の高い大型構造物などに対 しては法令などにより，また具体的な実施手順等につい ては，JIS 規格，各種団体規格など既存の規格・基準を引 用し規定している場合が多い.JIS 規格の制定及び改正に 際しては，最近の国際化社会を反映して ISO（国際標準 化機構）規格が引用されるのが基本である。これは，国 際的な障害を排除し貿易の不均衡をなくすことを共通認 識として，強制規格及び任意規格ともに国際規格との整 合化に配慮してのことである。そのため，できる限り ISO の考え方を取り入れる方向で実情に配慮したJIS 規格 の制定，改正が行われている。国際規格の JIS 規格など への採用において国際規格との同等性の程度は「一致 (IDT) 」，「修正 (MOD)」及び「同等でない (NEQ)」に 分類されており，「一致」及び「修正」が国際規格を採用 していることになる．国際規格は，規格作成プロセスで の透明性, 公開性, 平等性が確保されること, 及び作成 された国際規格は世界の市場のニーズを適切に反映した ものであることが必要となっている．非破壊試験に関し ては，ISO/TC135（非破壊試験に関する専門委員会）に 相当する欧州における委員会は CEN TC138 であり, 近年, これには TC135 議長あるいは幹事（現在は日本が議長・ 幹事国）が Observer の形で参加して相互の連携を図って いる ${ }^{1,2)}$. ISO に対する日本の標準化活動は，これまでの 長い間，他の先進工業国と比較すると受け身的であった。 
非破壊試験分野においても日本からの国際規格原案を提 出することは少なく，他国の規格案に対するコメントの みにとどまっていた。しかし（社）日本非破壊検査協会 が1992年に TC135 の幹事国業務を，1995年に SC6（漏れ 試験）の幹事国業務を受けて以来，国内はもとより国際 的にもより積極的な活動を展開してきている31. 一方，国 家規格と民間団体規格との比較において，一般に直接的 な公的関与の多少に応じて分類し，強制法規における強 制基準，公的標準（いわゆる「デジュール標準」），非公 的標準（「デファクト標準」）及び標準化されないものに 分類され JIS 規格はデジュール標準，（社）日本非破壊検 査協会規格の NDIS あるいは（社）日本溶接協会規格の WESのような規格はデファクト標準として分類されるこ とになる1)

\section{3 非破壊試験関連規格及び技術の動向}

非破壊試験関連の ISO 規格について TC135 は勿論のこ と，「溶接」の専門委員会である TC44,「鋼」の専門委員 会である TC17でも取り扱っている規格が少なくない. 一方，近年 TC108（Mechanical vibration and shock）で は機器の状態監視, 診断に前述の $\mathrm{AE}$ あるいはサーモグ ラフィを用いて試験する際の技術者の認定に関する規格 の制定が進められている。2008年 3 月現在で1998年から 2007年までの TC135における ISO 関連規格の制定等の状 況は以下のようである。共通規格として TC135では ISO9712（非破壊試験一技術者の資格認証）が2005年に改 訂され，非破壊試験の一般用語の定義は Technical Specification としてTS18173 が，更に資格試験に用いら れる試験体の不連続部に関してTS22809 として制定され た他 2 件である。TC44（溶接関連専門委員会）では FDIS（Final Draft ISO）に関して，超音波探傷試験では オーステナイト系ステンレス鋼及びニッケル基合金溶接 継手など 4 件, 磁粉探傷試験, 浸透探傷試験及び渦電流 試験がそれぞれ 1 件である．なお，超音波探傷試験規格 でTC44で扱うステンレス鋼溶接部に関わる規格がここ 数年増加の傾向にある. 一方, 渦電流探傷試験規格につ いて TC44 では 1 件もないが，TC135 では ISO/DIS （Draft ISO）として，用語の定義，一般原則，装置に関す る性能等 5 件が審議中であり，いずれは ISO 規格となる. 従って，ISO 規格がない現在，今後は日本からの意見を 積極的に提案していく予定となっている2). 一方，目視試 験規格として TC135 では表面試験の金属組織レプリカ及 び目視検査の手段一低倍率拡大レンズの選択の 2 件, TC44 では 1 件のみで, 2005年に溶融継手の外観試験とし て JISZ3090を制定している. TC17 は鋳鋼品の表面品質 の目視試験と定義の 1 件となっている2,4).

ISO 関連規格以外では CEN（ヨーロッパ標準化委員会） の $\mathrm{EN}$ 及び BS（イギリス規格協会），米国の ASTM（米 国材料試験協会)，ANSI（米国規格協会)，ASME（米国 機械学会）などにおいて多くの規格を制定している4. 国 内の民間団体規格としては NDIS や WES などの他，（社） 軽金属溶接構造協会, (社) ステンレス構造建築協会, （社）日本圧接協会，（社）日本アルミニウム協会，（社）
日本エルピーガスプラント協会，（財）日本海事協会， （社）日本軽量機器工業連合会，（社）日本建築学会，（社） 日本コンクリート工学協会, (社) 日本電機工業会なども 非破壊試験に関連する独自の協会規格を制定している. なお，国内規格として（社）日本非破壊検査協会が制定， 改正，確認の見直しなどを行っている JIS 規格を参考ま でに挙げると，2008年 1 月現在，共通関連では 8 件，資 格及び燃焼関連では 3 件，放射線関連で 17 件，超音波関 連で25件, 磁粉・浸透関連で11件, 渦電流・漏洩関連で7 件, 漏れ関連で 6 件, $\mathrm{AE}$ では 1 件である. 一方, 団体規 格としての NDIS 規格では， 3 件の目視試験関連規格, 9 件のひずみ関連規格， 4 件のサーモグラフィ試験関連 規格， 9 件のコンクリート関連規格， 1 件の電位差法に 関連する規格など，およそ60件である.

次に, 非破壊検査の動向として主な試験技術を挙げる. 放射線透過試験関連では，主流であるX線フィルムによる ラジオグラフィに代わって，イメージングプレートに代 表されるデジタルラジオグラフィが, 撮影後の画像処理 技術による三次元映像化をより実用的なものにしている. さらに画像の管理，画像による計測技術等の活用が期待 されるが，デジタルラジオグラフィ技術の実用化には JIS 化が当面の課題でもある。一方，検査の適用は構造物の 溶接部からコンクリート, 小型電子部品や文化財などに 拡大が図られてきており，これに伴うマイクロフォーカ ス X 線装置, あるいは大型構造物への適用のための高エ ネルギーX 線装置としての電子線加速器などの開発研究 も進んできている.

超音波探傷試験関連ではガイド波，非線形超音波，フ エーズドアレイシステム等の適用が注目されてきている. ガイド波は, ここ数年配管への広領域超音波探傷手法と しての利用が増えつつあり，鉄道レール，石油タンク， ボイラーチューブなどのきず及び減肉などの検査への実 機適用に向けた検討も行われている. また，き裂及び材 料の評価においてより微細なきず及び材料内部組織の変 化などの検出が可能な非線形超音波に関する研究が行わ れている。一方，倠の高さあるいは深さの高精度測定 技術に関し，特に原子力分野においてこれらの技術は PD (Performance Demonstration, 性能実証) 認証制度に取 り込まれた ${ }^{5,6)}$. 規格として NDIS 0603 が制定され，超音 波探傷試験技術者に対して探傷装置, 手順書と一括した 超音波探傷試験システムの性能実証が2006年 1 月から開 始された。なお，今後は原子力分野以外でのPD認証制度 の展開が期待される.PD では端部エコー法, フェーズド アレイ法, モード変換波法, TOFD (Time of Flight Diffraction：き裂先端部回折波伝搬時間測定）法の適用が 規定されている.この中で, フェーズドアレイ技術はき ずの検出あるいはサイジングに必須の技術として, 最近, 適用のための研究開発が多方面で進んでおり, 注目され てきている，今後はより高精度のき裂サイジング装置, き裂周りの波動解析シミュレーションとデジタル処理を 組み合わせた画像化技術の開発研究が進められるであろ う7). また, 非接触技術としてレーザー超音波, 電磁超音 波および空中超音波の試験研究も進められている ${ }^{8}$.

一方，表面探傷試験技術では上記 PD 制度の導入に伴 
うサイジングの影響を受け，維持基準の考え方が広まり， 保守検査におけるきずの定量性が求められ，き裂寸法の 定量評価，微小き裂の高感度検出，鋼板裏面のきずや腐 食の分布, 鋼材の材料評価等の方向への試験研究が渦電 流探傷試験，磁粉・漏洩磁束探傷試験分野において進ん でいる8

\section{4 まとめ}

以上，非破壊検査技術について品質保証と管理の観点 から述べたが，検査に係る試験技術は個々の試験成果を ベースとした標準化であり，国内では各種団体等による JIS の規格化である，と同時に国際規格（ISO）との整合
化でもある。したがって，今後は広範囲な各種団体等を 含めた体制での国内外の諸規格への対応が不可欠である と考える。

\section{文献}

1）大岡：非破壊検查による品質管理などに関する講習会資料 JSNDI, 2008.2

2) 大岡：非破壊検查, vol.56 (2007), No.8, pp427-434.

3）大岡：非破壊検查，vol.55 (2006), No.2, pp77-83.

4) JIS ハンドブック，非破壊検査，2007.

5) 大岡 : JWES RUMPES Vol.19, No.3, Autum, 2005.

6） NDIS 0603-2005「超音波探傷システムの性能実証における技術者 の資格拈よび認証」。

7）三原：非破壊検査, vol.56 (2007), No.8, pp394-399.

8）小井戸：非破壊検查，vol.56 (2007)，No.8，pp400-404 